\title{
Irrigation as a disturbance for interstitial crustacean communities in a French Pyrenean alluvial aquifer
}

\author{
P. Dumas
}

IRD, UR ELISA, BP 165, 97323 Cayenne, French Guiana. E-mail : dumas@cayenne.ird.fr

\begin{abstract}
While the impacts of groundwater contamination on interstitial invertebrate communities are well studied, very few work have examined other potential disturbance resulting from agricultural practices. In the present study, the interstitial crustacean fauna was studied in an alluvial aquifer characterized by intensive cereal irrigation, to test the influence of groundwater extraction on the assemblage characteristics (abundance, diversity, persistence, species distribution patterns). Micro- and macrocrustaceans were sampled at 4 seasons in 15 wells with contrasted groundwater use (cereal irrigation / domestic use / no groundwater use) scattered over a $250 \mathrm{~km}^{2}$ alluvial floodplain. The aquifer harbored diverse assemblages dominated numerically and specifically by cyclopoids. Total abundance, diversity expressed using species richness or Shannon index, overall persistence in species composition did not vary between stations whether micro- or macrocrustaceans were considered. Yet, marked differences in the cyclopoids assemblages composition were found in relation to groundwater utilization. Disturbed irrigation wells were dominated by epigean species, while hypogean species were mainly found in less impacted domestic wells. In contrast, amphipods/isopods did not exhibit particular assemblages composition between irrigation, domestic or abandoned wells. The differential responses between micro- / macrocrustaceans, epigean / hypogean species emphasized that levels of disturbance are strongly taxondependent. At the scale of the aquifer, these results suggest that groundwater extraction resulting from intensive irrigation has to be considered as a potential disturbance for the interstitial communities.
\end{abstract}

Keywords : disturbance, interstitial fauna, ground waters, aquifers.

\section{Introduction}

With the growing use of water by human populations, potential sources of disturbance for ground as well as surface waters progressively increased. Urban development, agricultural practices, river engineering associated to hydroelectric power production are thus well known causes of floodplain degradation and invertebrates communities alteration (Claret et al. 1999, Marmonier et al. 2000). The development of intensive cultivation in industrialized countries is one of the major threats for ground waters, and many authors emphasized the vulnerability of aquifers to agricultural practices such as fertilization, or the use of pesticides (see Gibert et al. 1994). Effects of agrochemical contamination on interstitial communities are for instance well documented in Europe and USA, from minor changes in assemblages structure to drastic reductions of diversity and/or abundance (e.g. Gibert et al. 1991, Boulal et al. 1997, Notenboom et al. 1994, Mösslacher \& Notenboom 1999).

Among other potential sources of disturbance for groundwater invertebrates, irrigation is poorly documented. However, by artificially increasing the variations of water-table and piezometric levels, groundwater extraction may also affect the interstitial communities. Evidence of changes in the structure of crustaceans assemblages that may be linked to groundwater supply was thus discussed in a recent paper (Dumas 2002). Yet, the influence of groundwater extraction on the invertebrates communities structure and dynamics is still questionable.

Invertebrates were studied in an alluvial aquifer where ground waters were mainly used for irrigation, the Ariège alluvial aquifer (French Pyrenees). Microand macrocrustacean assemblages were investigated in stations exhibiting contrasted difference in groundwater use (cereal irrigation / domestic use / no groundwater use), to elucidate : 1) the impact of contrasted water extraction regimes upon the interstitial fauna; and 2) the potential differences in community response between epigean (surface) and hypogean (groundwaterdwelling) species. 


\section{Material and methods}

\section{Study area}

All sites were scattered over the Ariège floodplain, a $250 \mathrm{~km}^{2}$ continental plain located in the north of the French Pyrenees. Population density and industrial activity are low in the area ; emphasis is on cereal intensive cultivation (maize) associated to strong, seasonal irrigation. The aquifer is formed by superposed sedimentary layers that constitute embedded alluvial terraces, with water supply mainly from rainwater run-off : in the area, rivers generally flow below the aquifer water-table and thus have very limited influence on ground waters (Cugny 1980). As ground water was needed for agricultural and domestic purposes, watersupply facilities were established in the last decades : they consist mainly in production wells, typically 1$1.50 \mathrm{~m}$ in diameter and equipped with an immersed pump, generally located close to the farms.

The sampling sites were 15 production wells, scattered over the whole floodplain. Depth range was 4-11 $\mathrm{m}$, with piezometric levels between 0.50 and $8.70 \mathrm{~m}$ (average $4.50 \mathrm{~m}$ ) below the soil surface. Hydrogeology as well as agriculture induced among-site variations in groundwater physico-chemical parameters, but previous studies established that water quality did not influence the interstitial fauna (Dumas \& Lescher-Moutoué 2001, Dumas et al. 2001).

Three categories of wells were sampled in relation to their general use (Table 1) :

A) Wells for cereal irrigation, with strong / seasonal groundwater extraction. In the area, irrigation generally lasted for 3 months (July-September) ; pumping rates ranged between 15 and $80 \mathrm{~m}^{3} \cdot \mathrm{h}^{-1}$;

B) Wells for domestic use (including drinking water, livestock, garden), with moderate / all-year groundwater extraction. Pumping range was $1-5 \mathrm{~m}^{3} \cdot \mathrm{h}^{-1}$;
C) Well abandoned for 3 years.

Sampling was carried out on four occasions between 1998 and 2000, in order to cover two complete hydrological years. The surveys were performed at the beginning of October 1998 / October 1999 (low water periods), April 1999 / April 2000 (high water periods).

\section{Invertebrate sampling}

Invertebrates were collected with two complementary devices, following Boulal (1988) : a phreatobiological net-sampler (Cvetkov 1968, Bou 1974) with 90 $\mu \mathrm{m}$-mesh size, drawn up 10 times in each well through the entire water column, and a $90 \mu \mathrm{m}$-mesh plankton net used to filter the groundwater extracted with an immersed centrifugal pump. After preliminary tests, the volume of water extracted with the pump was standardized at $2 \mathrm{~m}^{3}$. Animals were preserved in the field in $70 \%$ ethanol.

As previous comparative studies showed that both devices provided similar results with respect to faunal composition and species relative abundances (Dumas $\&$ Fontanini 2001), the invertebrates collected with the two methods were systematically grouped together. The samples collected using this procedure could be considered representative of the alluvial aquifer invertebrate communities (Dumas et al. 2001).

In the laboratory, specimens were stained using Rose bengal in order to distinguish them easily, then sorted in Dolfuss chambers under a stereomicroscope. For cyclopoids, sub-sampling was used for samples with very high animal densities. Afterwards, all specimens were identified and counted under a Nachet $300 \mathrm{mi}-$ croscope.

Macrocrustaceans (isopods and amphipods) were all identified to species level. For microcrustaceans, eight cyclopoids taxa were identified to species level. Small,

Table 1. Main characteristics of the 3 groups of stations in the Ariège alluvial aquifer (groundwater general use and extraction regimes, number of sampled stations and depth).

\begin{tabular}{ccccccc}
\hline Group & $\begin{array}{c}\text { Groundwater } \\
\text { use }\end{array}$ & $\begin{array}{c}\text { Extraction } \\
\text { period }\end{array}$ & $\begin{array}{c}\text { Pumping } \\
\text { range }\left(\mathrm{m}^{3} \cdot \mathrm{h}^{-1}\right)\end{array}$ & $\begin{array}{c}\text { Number of } \\
\text { stations }\end{array}$ & $\begin{array}{c}\text { Mean depth } \\
(\mathrm{m})\end{array}$ & $\begin{array}{c}\text { Mean } \\
\text { diameter (m) }\end{array}$ \\
\hline A & irrigation & July-September & $15-80$ & 7 & 9.50 & 1.20 \\
B & domestic & all year & $1-5$ & 7 & 7 & 1.00 \\
C & none & - & - & 1 & 9.60 & 1.00 \\
\hline
\end{tabular}


rare individuals of Speocyclops sp. and Graeteriella sp. were identified to genus. Diacyclops languidoides, D. clandestinus and the very rare D. languidus were grouped together as Diacyclops spp. (See Dumas \& Fontanini 2001 for details on sampling procedures).

\section{Statistical analyses}

Variations in crustacean assemblages characteristics between the stations were investigated using non-parametric one-way analyses of variance (Kruskal-Wallis ANOVA, Zar 1984) : total species richness, total abundance, Shannon-Weaver index of diversity and Ken-

Table 2. Composition of the groundwater macro- and microcrustaceans assemblages in the 3 groups of stations. Groups A, B, C : groundwater for irrigation, domestic use and no groundwater extraction, respectively. $\mathrm{n}:$ total number of individuals collected in all the stations. Abundance $\%$ : percentage of total abundance of each species for the considered group of stations. Occurrence $\%$ : percentage of samples in which the species was found for the considered group of stations. Stygobite (hypogean) species are marked with an asterisk (*).

\begin{tabular}{|c|c|c|c|c|c|c|c|}
\hline \multirow[b]{2}{*}{ Microcrustaceans } & \multirow{2}{*}{$\frac{\text { All }}{\mathbf{n}}$} & \multicolumn{2}{|c|}{ Group A } & \multicolumn{2}{|c|}{ Group B } & \multicolumn{2}{|c|}{ Group C } \\
\hline & & $\begin{array}{c}\text { Abundance } \\
\%\end{array}$ & $\begin{array}{c}\text { Occurrence } \\
\%\end{array}$ & $\begin{array}{c}\text { Abundance } \\
\%\end{array}$ & $\begin{array}{c}\text { Occurrence } \\
\%\end{array}$ & $\begin{array}{c}\text { Abundance } \\
\% \\
\end{array}$ & $\begin{array}{c}\text { Occurrence } \\
\%\end{array}$ \\
\hline \multicolumn{8}{|l|}{ Cyclopoida } \\
\hline Macrocyclops albidus & 1272 & 21.93 & 40 & 2.83 & 33.33 & 75.24 & 26.67 \\
\hline Eucyclops serrulatus & 13603 & 91.65 & 58.97 & 8.35 & 41.03 & 0 & 0 \\
\hline Tropocyclops prasinus & 33370 & 12.61 & 44.12 & 48.93 & 47.06 & 38.45 & 8.82 \\
\hline Paracyclops fimbriatus & 6611 & 62.20 & 44.12 & 37.73 & 52.94 & 0.07 & 2.94 \\
\hline Acanthocyclops viridis & 1 & 0 & 0 & 100 & 100 & 0 & 0 \\
\hline Diacyclops bicuspidatus & 40 & 92.50 & 66.67 & 7.50 & 33.33 & 0 & 0 \\
\hline Diacyclops bisetosus & 26215 & 5.42 & 35.71 & 94.47 & 57.14 & 0.11 & 7.14 \\
\hline Diacyclops spp.* & 31559 & 6.48 & 43.90 & 93.19 & 48.78 & 0.33 & 7.32 \\
\hline Speocyclops sp.* & 84 & 95.29 & 60 & 4.71 & 40 & 0 & 0 \\
\hline Graeteriella unisetigera* & 131 & 0 & 0 & 99.24 & 80 & 0.76 & 20 \\
\hline Graeteriella sp.* & 11 & 27.27 & 25 & 72.73 & 75 & 0 & 0 \\
\hline Macrocrustaceans & & & & & & & \\
\hline
\end{tabular}

Amphipoda

Salentinella petiti*

Niphargus gineti*

$151 \quad 71.52$

60

13.39

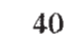

0

Niphargus pachypus*

32

60.87

28.48

39.13

0

Niphargus robustus*

2233

90.63

75

9.38

25

44.74

Niphargus gallicus*

15

40.93

9.40

44.74

49.66

10.53

$26 \quad 73.08$

100

0

0

0

0

Niphargus n. sp.*

17

42.86

26.92

57.14

100

100

0

0

0

0

$$
0
$$

Isopoda

\begin{tabular}{lrrrrrrrr} 
Proasellus meridianus & 186 & 99.46 & 87.50 & 0.54 & 12.50 & 0 & 0 \\
Stenasellus virei ${ }^{*}$ & 47 & 38.30 & 42.86 & 42.55 & 42.86 & 19.15 & 14.29 \\
\hline
\end{tabular}


dall coefficient of concordance (constancy in rank position of the species in terms of relative abundances among surveys, Siegel 1956) were compared between the 3 groups of wells for both micro- and macrocrustacean taxa. Influence of groundwater extraction upon the assemblages was assessed using factorial discriminant analyses (FDA, Cailliez \& Pages 1976). The data matrix was first modified by separating microcrustacean from macrocrustacean taxa, the latter having low abundances in comparison with cyclopoids. Samples were then grouped by station in relation to groundwater use : 3 groups were constituted. Discrimination between these groups of samples was tested using FDA performed on the species relative abundances ; significance was assessed using the Wilk's test (Saporta 1990). All data were plotted on FDA diagrams to explore the relationships between groundwater extraction and community structure for micro- and macrocrustaceans.

\section{Results}

\section{Collected taxa}

Groundwater assemblages were dominated by microcrustaceans (cyclopoids), whether species richness or total abundance was considered (Table 2). Eleven microcrustacean and 9 macrocrustacean taxa were found in the samples. Widely-distributed, epigean species were associated with hypogean (stygobite) species for microcrustaceans while the majority of the macrocrustaceans collected ( 8 of the 9 species) were stygobites.

Epigean and hypogean cyclopoid taxa tended to cooccur in the 3 groups of stations : E. serrulatus, P. fimbriatus, D. bicuspidatus and the very rare Speocyclops sp. were frequently collected in stations from group A. T. prasinus, D. bisetosus, Diacyclops. spp. and Graeteriella species characterized samples from group B, while M. albidus was mainly found in group C.

Table 3. Variations in the groundwater assemblages in relation to groundwater extraction regimes. Species richness, Shannon-Weaver diversity index, total number of individuals collected per sample and Kendall's coefficient of concordance for micro- and macrocrustaceans taxa. Means, standard deviations (in parentheses). Kruskall-Wallis ANOVAs (H coefficient and probability). n= number of samples.

\begin{tabular}{cccccc}
\hline & $\begin{array}{c}\text { Irrigation } \\
(\mathrm{n}=27)\end{array}$ & $\begin{array}{c}\text { Domestic } \\
(\mathrm{n}=28)\end{array}$ & $\begin{array}{c}\text { No extraction } \\
(\mathrm{n}=4)\end{array}$ & $\mathrm{H}$ & $\mathrm{p}$ \\
\hline Microcrustaceans & & & & & \\
Species richness : & & & & & \\
$\quad$ epigean & $2.63(1.04)$ & $2.61(1.20)$ & $2.50(0.58)$ & 0.03 & 0.99 \\
$\quad$ hypogean & $0.82(0.62)$ & $1.04(0.58)$ & $1(0.82)$ & 2.24 & 0.33 \\
$\quad$ total & $3.44(1.22)$ & $3.64(1.55)$ & $3.5(0.58)$ & 0.13 & 0.94 \\
Diversity index (H) & $0.68(0.49)$ & $1.00(0.64)$ & $0.59(0.42)$ & 3.75 & 0.15 \\
Abundance & $929.6(848.6)$ & $2667(6648)$ & $3494(6635)$ & 4.67 & 0.10 \\
Kendall index (W) & $0.71(0.16)$ & $0.64(0.26)$ & 0.55 & 0.66 & 0.72
\end{tabular}

\section{Macrocrustaceans}

Species richness :

\begin{tabular}{lccccc} 
epigean & $0.26(0.45)$ & 0 & 0 & 9.25 & $<0.01$ \\
hypogean & $2.48(1.12)$ & $1.74(1.16)$ & $1.5(0.58)$ & 6.08 & $<0.05$ \\
total & $2.74(1.32)$ & $1.74(1.16)$ & $1.5(0.58)$ & 8.78 & $<0.05$ \\
index (H)' & $0.78(0.63)$ & $0.67(0.57)$ & $0.07(0.11)$ & 4.47 & 0.11 \\
index $(\mathrm{W})$ & $82.1(92.2)$ & $15.7(18.4)$ & $279.5(125.1)$ & 22.58 & $<0.01$ \\
\hline
\end{tabular}


Distribution patterns differed for macrocrustaceans, mainly collected in the stations from group A (all species except amphipod N. pachypus, found only in station from group $\mathrm{C}$, and isopod $S$. virei, mostly found in those from group B). Rare species thus tended to occur in a single group of stations.

\section{Assemblage characteristics}

\section{Microcrustacean assemblages}

The number of individuals collected showed great variations in the samples, from a few tens to more than 32000 . Although the total abundance slightly varied among the 3 groups of stations (with a small trend to increase from group A to group C), difference was not significant (Kruskall-Wallis ANOVA, Table 3).

1-6 cyclopoid species were found in the samples but species richness did not vary between the 3 groups, whether epigean, hypogean or total species were considered (n.s., Kruskall-Wallis ANOVA). Neither of diversity (expressed using Shannon-Weaver index) or temporal persistence (expressed using Kendall coefficient of concordance) had significant variations for cyclopoid assemblages between the groups considered.

\section{Macrocrustacean assemblages}

The range observed for the total number of specimens collected in the samples was lower than for microcrustaceans (from 0 to more than 400). Increasing abundance was found between stations from groups B, A, C respectively ( $<<0.01$, Kruskall-Wallis ANOVA) : the station with no groundwater extraction had the highest number of individuals (mean specimens per sample, $n=280$ ) compared to the other groups of stations (group A, $\mathrm{n}=82$ / group $\mathrm{B}, \mathrm{n}=12.5$ ).

The number of species in the samples ranged from 0 to 6 . Species richness also varied, with decreasing diversity from group A to group $\mathrm{C}$ for both hypogean or total species $(\mathrm{p}<0.05$, Kruskall-Wallis ANOVA). The same trend was observed for diversity expressed as Shannon-Weaver index but was not significant (n.s., Kruskall-Wallis ANOVA).

In the same way, Kendall coefficient of concordance did not exhibit significant differences between the 3 groups of stations.

\section{Community structure and groundwater extrac- tion}

FDA were performed on the data, in order to inves- tigate influence of groundwater extraction on the community structure.

\section{Microcrustacean assemblages}

The 3 groups of stations were well discriminated along the factorial axes (Fig. 1). Percentage of wellranked samples was high (78\%, Table 4$)$.

The horizontal axis (F1, $65 \%$ of total inertia) displayed a major pattern strongly separating samples from group $\mathrm{C}$ (on the right of the diagram) from those from groups A and B (on the left). Discrimination was high and significant (discriminant power on $\mathrm{F} 1=0.62$, $\mathrm{p}<0.001$, Wilk's test). The vertical axis (F2, $35 \%$ of total inertia) significantly opposed group A (upper part of the diagram) and group B (lower part of the diagram) samples (discriminant power on F2 $=0.47$, $\mathrm{p}<0.001$, Wilks test).

Assemblages clearly differed in these groups :

- Samples from group A were characterized mainly by $E$. serrulatus (number of individuals collected in ir-

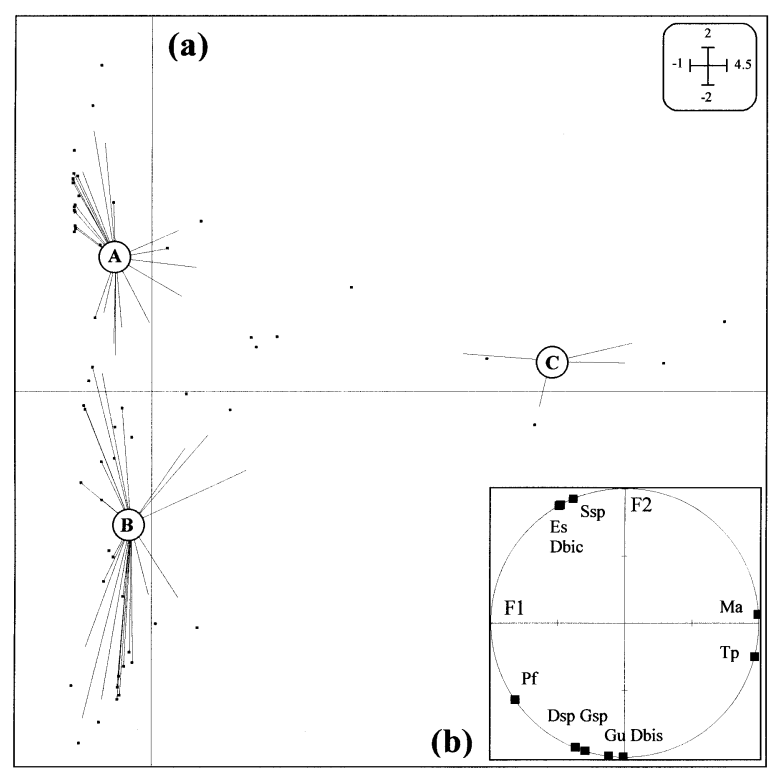

Fig. 1. Discrimination of microcrustacean assemblages in relation to groundwater use. FDA ordination (axes 1 and 2) of the sampling wells based on their taxonomic composition (cyclopoid species). A, B, C: centers of gravity for samples from irrigation, domestic and abandoned wells respectively (lines shortened to lighten the figure). (a) station plot, (b) variable plot. Ma: Macrocyclops albidus, Es: Eucyclops serrulatus, Tp: Tropocyclops prasinus, Pf: Paracyclops fimbriatus, Dbis: Diacyclops bisetosus, Dbic: Diacyclops bicuspidatus, Dsp: Diacyclops spp., Gu: Graeteriella unisetigera, Gsp: Graeteriella sp., Ssp: Speocyclops sp. 
Table 4. Discriminant analyses for groundwater assemblages based upon groundwater extraction. Percentage of well-ranked stations, discriminant power (correlation with factorial axes), Wilk's coefficient and associated levels of significance (p) for microcrustacean (cyclopoid) and macrocrustacean (amphipod + isopod) taxa.

\begin{tabular}{ccc}
\hline & Microcrustaceans & Macrocrustaceans \\
\cline { 2 - 3 } \% well-ranked & $\mathbf{7 8}$ & 64.4 \\
\hline Discriminant power & 0.62 & 0.27 \\
F1 axis: & 0.47 & 0.17 \\
F2 axis: & & \\
Wilk's coefficient (W) & 83.39 & 26.16 \\
F1 axis: & 32.92 & 9.50 \\
F2 axis: & & \\
Levels of significance (p) & $<0.001$ & 0.096 \\
F1 axis: & $<0.001$ & 0.301 \\
F2 axis: & &
\end{tabular}

rigation wells : n>12 000, i.e. $91.65 \%$ of all E. serrulatus collected), D. bicuspidatus $(\mathrm{n}=37,92.5 \%)$ and the hypogean Speocyclops sp. $(\mathrm{n}=81,95.3 \%)$ (correlation with $\mathrm{F} 2$ from 0.87 to 0.92 ) ;

- Samples from group B were dominated by $D$. bisetosus (n>24 000, 94.5\%), P. fimbriatus ( $>2000,37.8$ $\%)$ and the hypogean taxa Diacyclops sp. (n>29 000, $93.2 \%)$, G. unisetigera $(\mathrm{n}=130,99.2 \%)$ and Graeteriella $\mathrm{sp} .(\mathrm{n}=8,72.7 \%)$ (correlation with $\mathrm{F} 2$ from -0.57 to -0.99$)$

- Samples from group C were characterized by 2 species, $M$. albidus $(\mathrm{n}=957,75.2 \%)$ and $T$. prasinus (n>12 000, $38.5 \%$ ) (correlation with F1 0.99 and 0.97, respectively).

\section{Macrocrustacean assemblages}

In contrast, discrimination was low along the factorial axes (Fig. 2). Samples from the 3 groups of stations were scattered over the diagram (well-ranked samples : $64 \%$, Table 4) with most samples located close to the centre of the diagram, i.e. having low correlations with the axes. Discriminant power was low for the 2 factorial axes (F1 : 0.27, n.s. / F2 : 0.17, n.s.). Unlike microcrustaceans, no clear patterns in community structure could then be identified in the 3 groups of stations for amphipod / isopod taxa.

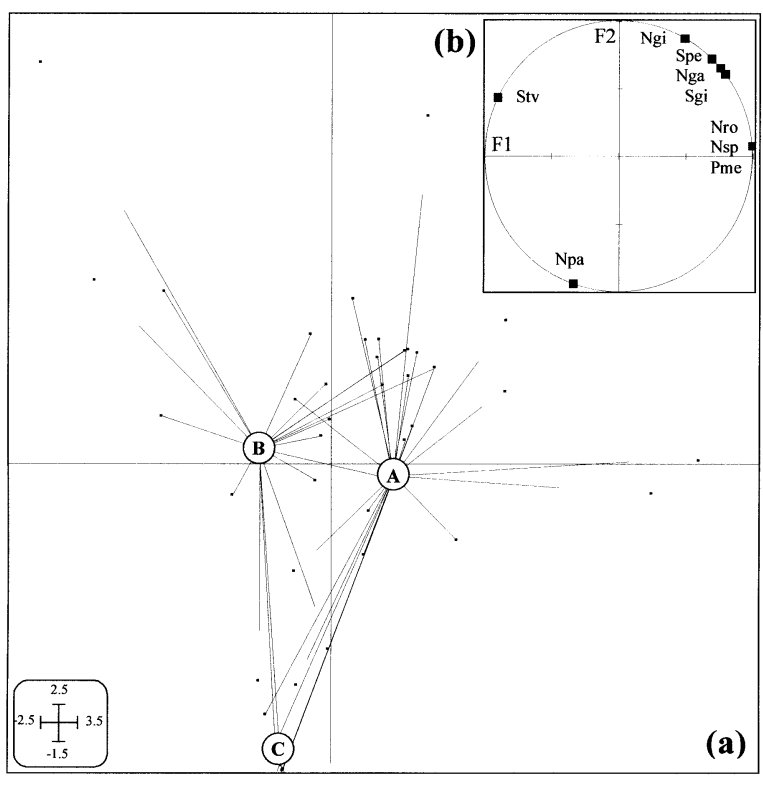

Fig. 2. Discrimination of macrocrustacean assemblages in relation to groundwater use. FDA ordination (axes 1 and 2) of the sampling wells based on their taxonomic composition (amphipod and isopod species). A, B, C: centers of gravity for samples from irrigation, domestic and abandoned wells respectively (lines shortened to lighten the figure). (a) station plot, (b) variable plot. Stv: Stenasellus virei, Npa: Niphargus pachypus, Ngi: Niphargus gineti, Nga: Niphargus gallicus, Nro: Niphargus robustus, Nsp: $\mathrm{Ni}$ phargus sp., Sgi: Salentinella gineti, Spe: Salentinella petiti, Pme: Proasellus meridianus. 


\section{Discussion}

In floodplains, the use of pumping devices for water supply results not only in groundwater extraction, but also in the removal of living organisms from parts of the aquifer in the vicinity of the wells or piezometer. As water velocity is artificially increased, invertebrates are dislodged from an area proportional to the shear stress induced (Danielopol 1976, Malard et al. 1997) : the higher the pumping rates, the larger the effective area. Moreover, when water supply is for intensive irrigation, significant volumes of water are generally extracted from aquifers through high pumping regimes : in the Ariège aquifer, values range from 7 to $160 \mathrm{~m}^{3} / \mathrm{h}$ in 168 agricultural wells scattered over the whole floodplain, with an average of $43 \mathrm{~m}^{3} \cdot \mathrm{h}^{-1}$. In addition to variations in groundwater velocity, variations in piezometric levels also constitute potential sources of disturbance for the interstitial invertebrates communities.

\section{Influence of water extraction upon abundance / diversity}

In the Ariège aquifer, no evidence of changes due to water extraction arose from simple measurements of abundance/diversity, at least for cyclopoids : none of the investigated variables (species richness for both epigean / hypogean taxa, abundance, Shannon H', Kendall W) showed clear patterns between abandoned / domestic / irrigation wells. The total number of specimens collected in particular did not follow any clear decreasing pattern in the most disturbed (i.e. irrigation) stations, while preliminary tests in strongly exploited production wells from the same area had revealed drastic reductions of invertebrates density ( 6 wells for drinking water supply sampled in April 1998 ; cyclopoid density from 0.1 to 13 individuals per $\mathrm{m}^{3}$ ). Yet, in the latter stations the intensity of disturbance was much higher as pumping was during all the year, with similar pumping rates. Thus, in the Ariège aquifer, a 3-months irrigation period does not seem to induce a dramatic decrease in microcrustaceans abundance, at least over the considered 2-years period. In contrast, amphipods/isopods exhibited differential patterns between the wells : abundance was significantly higher in the samples from the undisturbed, abandoned station. Diversity showed an inverted pattern, but the difference was actually low (species richness from 1.5 to 2.74 ) and does not represent any marked variation in the composition of the assemblages.
Yet, these results have to be carefully considered because of the low number of samples from the group $\mathrm{C}$ (4 samples). Despite our efforts, a single abandoned well (ancient irrigation well) was found over the area. This may cause samples from undisturbed situations to be under-represented, thus generalizations concerning abondance/diversity patterns may be hazardous at this point.

\section{Groundwater extraction and community structu-} re

At the scale of the floodplain, the results obtained using an alternative approach (multivariate analyses) suggest that groundwater extraction regimes influenced the cyclopoid assemblages. Disturbance caused by water extraction induced (at least partly) changes in the species composition, according to the intensity / frequency of pumping :

- The most disturbed stations (irrigation wells) harbored assemblages strongly dominated by 2 surface species (E. serrulatus, D. bicuspidatus) ; a single hypogean taxon (Speocyclops sp.) was also found in these wells but in very low abundance.

- Stations with intermediate disturbance (domestic wells) were characterized by an association of epigean (D. bisetosus, P. fimbriatus) and hypogean species, these latter (Diacyclops sp., G. unisetigera, Graeterialla $\mathrm{sp}$.) dominating the assemblages.

- The undisturbed station (abandoned well) displayed an original pattern with 2 ubiquist, surface species (M. albidus, T. prasinus).

Similar results were found by Rouch et al. (1993) for harpacticoid assemblages from a Pyrenean karstic system during a high-discharge pumping experiment $(810$ $\mathrm{m}^{3} \cdot \mathrm{h}^{-1}$ during 54 hours) : populations exhibited marked changes in assemblage composition and, one year later, they had still not recovered.

The absence of all hypogean taxa (except rare Speocyclops sp.) in agricultural, impacted wells emphasized a difference in community response between surface and groundwater-dwelling species. Although trying to infer biological or ecological traits from these results is hazardous, the observed patterns may express the differential success of epigean/hypogean species to withstand variable environmental conditions. Surface species could then be advantaged in unstable conditions caused by intensive groundwater extraction (such as encountered in agricultural wells) while less tolerant, hypogean ones would still persist in distant parts of the aquifer or in stations with more stable en- 
vironmental conditions, e.g. domestic wells (patch dynamics concept, Townsend 1989).

In the context of this work however, generalizations concerning community responses may be premature. As for abondance/diversity patterns, the restricted number of samples considered to illustrate the undisturbed situation should be kept in mind. While differences between the 14 domestic and agricultural wells clearly arises from the results, for cyclopoids the discrimination of the abandoned well on the right part of the horizontal FDA axis was thus based on 4 samples only. Yet, as species relative composition exhibited a strong constancy in the samples, this highlighted the originality of the assemblages from the undisturbed station.

The absence of hypogean taxa in this well also raises the problem of local factors that may potentially influence the assemblages. Physical (hydrodynamics, sediment characteristics), chemical (nutrients availability, groundwater quality) or biological (biotic interactions) factors may then be partly responsible for the observed patterns in this station : Danielopol (1989) emphasized the importance of local factors to understand the small-scale distribution of groundwater invertebrates. In contrast, amphipods/isopods assemblages did not reveal any clear patterns related to water extraction : despite an increase in total abundance in the abandoned well, species were collected in stations regardless of groundwater use in the stations. This statement is consistent with previous results : Dumas et al. (2001) showed that the spatial distribution of macrocrustaceans was strongly related to hydrogeology and hydrodynamics in this aquifer. As a matter of fact, at the scale of the Ariège floodplain, irrigation does not constitute a main disturbance for the macrocrustaceans assemblages.

\section{Taxon-dependent effects}

As dislodgment velocity and drift behavior differ between taxonomic groups, the taxon-dependent feature of pumping devices was often reported by authors (Idennacher 1985, Hakenkamp \& Palmer 1992, Malard et al. 1994). Danielopol (1976) thus found preferential removal of small, creeping invertebrates (Oligochaeta, Nematoda, Harpacticoida) in the first 10 liters of water sampled with a Bou-Rouch pump, while cyclopoids, amphipods and isopods were relatively constant in the following 10-1 samples. Testing different pumping devices, Malard et al. (1997) classified the invertebrates taxa according to their decreasing resistance to displacement by the current : amphipods and isopods had higher dislodgment velocities than cyclopoids. The patterns observed in the Ariège aquifer where only cyclopoids were affected by groundwater extraction are consistent with these results and may illustrate, at least partly, a similar taxon-dependent effect : in the area, pumping regimes in irrigation wells may cause sufficient disturbance to affect less-tolerant, small-sized microcrustaceans species but not larger, more resistant macrocrustacean species. Bearing in mind that this hypothesis will require further testing, irrigation should be recognized in future as a potential source of disturbance for groundwater interstitial communities.

\section{Acknowledgements}

The author wishes to thank F. Lescher-Moutoué, C. Bou for expert help with specimens determination, D. Danielopol for help, useful discussions, and comments.

This work was partially funded by grants from the French (AdourGaronne) Water Agency, and the Ariège Regional Council.

\section{References}

Bou C. 1974. - Les méthodes de récolte dans les eaux souterraines interstitielles. Ann. Spéléol., 29, 611-619.

Boulal M. 1988. - Recherches écologiques sur la faune aquatique des puits de la région de Tiznit (Anti-Atlas occidental, Maroc). Doctoral thesis, Univ. Marrakech, Morocco, $228 \mathrm{p}$.

Boulal M., Touyer A. \& Boutin C. 1997. - Qualité de l'eau et faune des puits près d'Agadir, dans le secteur aval de la plaine du Souss (Maroc). Bull. Soc. Hist. Nat. Toulouse, 133, 59-70.

Caillez F. \& Pages J.P. 1976. - Introduction à l'analyse des données. Société de Mathématiques Appliquées et de Sciences Humaines, Paris.

Claret C., Marmonier P., Dole-Olivier M.J. \& Castella E. 1999. - Effects of management work on the interstitial fauna of floodplain aquatic systems. Biodiv. Conserv., 8, 1179-1204.

Cugny M.T. 1980. - Aptitude à l'aménagement de la plaine alluviale de l'Ariège, facteurs hydrogéologiques et hydropédologiques. Doctoral thesis, Univ. Toulouse, 193 p.

Cvetkov L. 1968. - Un filet phréatobiologique. Bull. Inst. Zool. Mus. Acad. Bulgar. Sci., 27, 215-218.

Danielopol D.L. 1976. - The distribution of the fauna in the interstitial habitats of riverine sediments of the Danube and the Piesting (Austria). Int. J. Speleol., 8, 23-51.

Danielopol D. L. 1989. - Groundwater fauna associated with riverine aquifers. J. N. Amer. Benthol. Soc., 8, 18-35.

Dumas P. \& Fontanini G. 2001. - Sampling the fauna in aquifers: a comparison of net-sampling and pumping. Arch. Hydrobiol., 150, 661-676.

Dumas P. \& Lescher-Moutoué F. 2001. - Cyclopoid distribution in an agriculturally-impacted alluvial aquifer. Arch. Hydrobiol., 150 , 511-528.

Dumas P., Bou C. \& Gibert J. 2001. - Groundwater macrocrustaceans as natural indicators of the Ariège alluvial aquifer. Int. Rev. Hydrobiol., 86, 619-633. 
Dumas P. 2002. - Stability of interstitial communities in an isolated alluvial aquifer. Hydrobiologia, 468, 63-76.

Gibert J., Marmonier P., Turquin M.J. \& Martin D. 1991. - Anthropogenic disturbance of surface landscape : consequences on groundwater ecosystems. In Terrestrial and aquatic ecosystems : perturbation and recovery. Ellis Horwood limited.

Gibert J., Danielopol D. L. \& Stanford A. 1994. - Groundwater ecology. Academic Press, San Diego.

Hakenkamp C. C. \& Palmer M. A. 1992. - Problems associated with quantitative sampling of shallow groundwater invertebrates. Proceedings first internat. Conf. Groundwater Ecol. American Water Ressources Association. Tampa, Florida, 101-110.

Idennacher B. 1985. - Ecologie d'une nappe phréatique superficielle. D.E.A. Université de Lyon I, 21pp.

Malard F., Reygrobellet J.L., Mathieu J. \& Lafont M. 1994. - The use of invertebrates communities to describe groundwater flow and contaminant transport in a fractured rock aquifer. Arch. Hydrobiol., 131, 93-110.

Malard F., Reygrobellet J. L., Laurent R. \& Mathieu J. 1997. - Developments in sampling the fauna of deep water-table aquifers. Arch. Hydrobiol., 138, 401-432.

Marmonier P., Claret C. \& Dole-Olivier M.-J. 2000. - Interstitial fauna in newly-created floodplain canals of a large regulated river. Regul. Riv. Res. Mgmt., 16, 23-36.
Mösslacher F. \& Notenboom J. 1999. - Biomonitoring of groundwater systems: methods, applications and possible indicators among micro- and macroorganisms. In Danielopol D., Griebler C., Gibert J., Nachtnebel H.P. \& Notenboom J. (eds), Groundwater Ecology, a tool for management of water resources - lecture notes.

Notenboom J., Plenet S. \& Turquin M.-J. 1994. - Groundwater contamination and its impact on groundwater animals and ecosystems. Pages 477-504 in Gibert J., Danielopol D. \& Stanford J. (Eds). Groundwater Ecology. Academic Press, San Diego, USA.

Rouch R., Pitzalis A. \& Descouens A. 1993. - Effets d'un pompage à gros débit sur le peuplement des crustacés d'un aquifère karstique. Ann. Limnol. 29: 15-29.

Saporta G. 1990. - Probabilités, analyse des données et statistique. Editions Technip, Paris.

Siegel S. 1956. - Non parametric statistics for the behavioural sciences. McGraw Hill, New York, USA.

Townsend C. R. 1989. - The patch dynamics concept of stream community ecology. J. N. Amer. Benthol. Soc., 8, 36-50. 